\title{
SUSTAINABILITY NAVAL BASE WITH THREE MAIN ASPECTS AS ONE OF THE INDONESIAN MARITIME DEFENSE AND SECURITY ELEMENTS WITH SYSTEM DYNAMIC APPROACH
}

\author{
Indra Agustian, Avando Bastari, Okol Sri Suharyo. \\ Indonesian Naval Technology College, \\ Bumimoro-Morokrembangan, Surabaya 60187, Indonesia
}

\begin{abstract}
The development of Naval Base requires very strategic planning and calculation to obtain the sustainability of the base. This is intended so that in the future the existence of these bases can continue and exist, which is not disturbed by changes and System Dynamics from various aspects that develop and change over time. Sustainability of Naval Base is determined by many factors that are interrelated with one another as a very complex system arrangement so that a comprehensive analysis of various related aspects of the researcher is compiled into Three main aspects namely Defense Security Political Aspects, Economic Aspects and physical aspects of naval base. In this paper, the researcher will compile a model with System Dynamics approach to the sustainability of the Naval Base that is the object. Then also use Fuzzy Weighting from the elements of subjectivity which will be projected to become elements of objectivity, which also involves data / variables that are qualitative and quantitative. This has never been discussed in previous site selection studies. The complexity of the variables and the dependency relationships between variables in the system, and the decision makers' subjectivity can be identified and smoothed with the Fuzzy Weighting to get the weighting value so that the integration between the System Dynamics model with the Fuzzy Weighting method gets the analysis results of the Naval Base sustainability system based on three main aspects namely Defense Security Political Aspects, Economic Aspects and Physical Aspects of Naval Base. The results of the assessment of Fuzzy Weighting put the Defense Security Political Aspects in the first place with the value of the weight of the influence of interest 3.60, followed by the second position of the Physical Aspects of Naval Base with the value of the weight of the influence of the interest 3.40 and in the third position the Economic Aspects with a value of 3.0. Then the results are integrated into the System Dynamic calculation that produces sustainability values from three main aspects including Defense Security Political Aspects with strategic value of base area 36.42, then from Economic Aspects with land availability value 3.94, and Physical Aspects of Naval Base with physical capability values base 21.07.
\end{abstract}

Keywords: Naval Base, Sustainability, Three Main Aspects, Fuzzy Weighting, System Dynamic.

\section{INTRODUCTION.}

Current national development policies that place the maritime sector as the backbone of the nation's economy need to be supported by building a respected maritime defense force in the region, aimed not only at maintaining sovereignty and protecting Indonesia's maritime glory, but also as a form of responsibility to safeguard maritime defense . This concept has the consequence of the need for a defense posture that has the power and ability not only to protect Indonesia's territorial territory and EEZ, but also to reach a wider area. (Navy Chief Regulation number / 5 / IV / 2016 dated 26 April 2016 concerning basic policies for the development of the Navy to the Minimum Essential Force)

The role of a naval base is very large to support the operation of warships to overcome all security threats and sovereignty in the region. The Naval Base is an element of territorial support for maritime defense and security so that the Naval Base has a strategic value to help safeguard national sovereignty, maritime defense and security in national jurisdictions by supporting the operation of Indonesian Navy ships that require facilities logistics and others for the sake of the continuity of the operation.

Referring to the aforementioned problems, the researcher intends to compile a Dynamic System model that can determine the sustainability of a Naval Base with the interaction relationship between Defense Security Political Aspects, Economic and Physical defense of the base, so that an understanding of the magnitude of the influence of these aspects on the sustainability of Naval Base, which aims to be projected whether the base is sustainable or not in the future.

The existence and sustainability of the Naval Base considers various complexities of factors that can influence the sustainability of the base. These factors are carried out by measurements including qualitative and quantitative data, where qualitative data is in the form of linguistic data that has not been quantitatively measured from the existing Warshipteria and will later be used as a value of the influence of the Warshipteria weights. The value of the influence of the Warshipteria weights which are 
qualitative data is quantified with an objective assessment using the Fuzzy Weighting method. Quantitative data which is measured data in the form of numbers and then combined with qualitative data values. This data grouping needs to be done because the two types of data require different data processing. Then after that the weight of the influence of the level of importance that uses Fuzzy Weighting is integrated with System Dynamic to get the right and accurate system modeling.

The compilation of the System Dynamic model is more emphasized on the existence of the sustainability of a naval base, because it is not only used in the current situation but also considered and projected for the sustainability of the base in the future so that it still exists, as one of the supporting elements of the force maritime defense and security and territorial sovereignty of the Indonesian state.

\section{MATERIALS AND METHODS.}

\subsection{System Dynamic Model}

System Dynamic model is a combination of theories, methods, and philosophies for analyzing the behavior of a dynamic system by building general models ranging from identifying symptoms to generating problem structures for simulation evaluation / policy analysis in making decisions, both for evaluating strategic steps taken has been taken in producing system performance, as well as for evaluation / analysis of alternative steps that need to be taken in achieving the desired goals going forward (Forester, 1994).

In Figure 1 in a dynamic system methodology there are six steps to solving problems that interact with each other to form a loop (Sushil, 1993), that is:
a. Problem identification and definition
b. Conceptualizing the system.
c. Model formulation.
d. Simulation and model validation.
e. Policy analysis and improvement
f. Policy Implementation

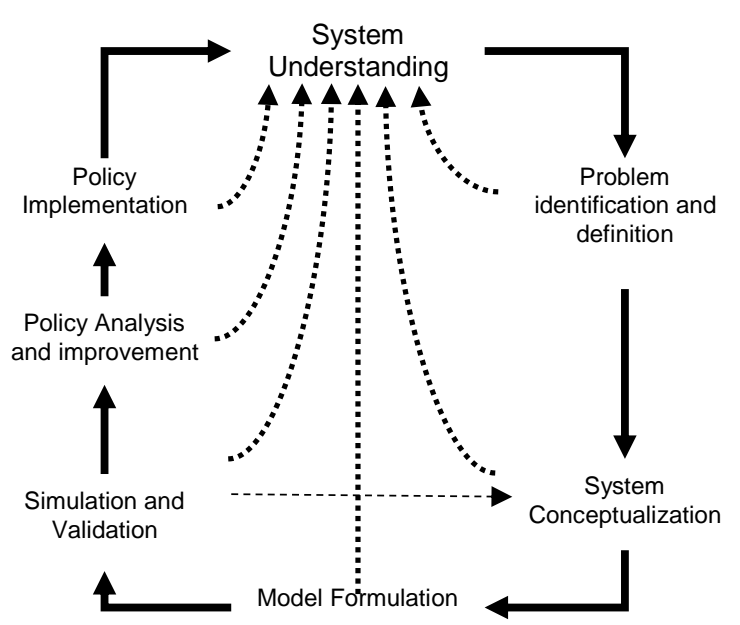

Figure 1 System Dynamic methodology (Sushil, 1993)

\subsection{Variables of System Dynamic Model.}

Figure 2. above is some System Dynamic model variables which are divided into three parts, namely

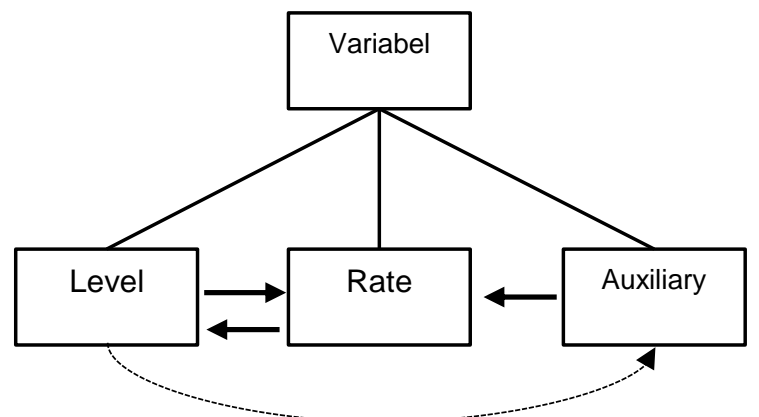

Figure 2. Types of Variables in a System Dynamic Model (Sushil, 1993)

Level, Rate and Auxiliary.

a. Level Variable

In a real system there are basically two types of levels, namely physical subsystems or information subsystems. Physical subsystems are related to the flow of physical resources, such as materials, labor, money, orders and so on. Information subsystem related to the flow of information in the system that connects physical entities. In Figure 2.4 the level variable represents the accumulation or integration of a flow over time.

b. Rate Variable

In Figure 3. Variable rate in the system is basically a decision variable governed by one or more policy structures. Rate will determine the flow of entry / exit both from / towards a level. The decision taken is to determine the influence of the rate at a time on the level and information about the system. Rate is measured by policies translated in the form of information flow that affects the variable rate.

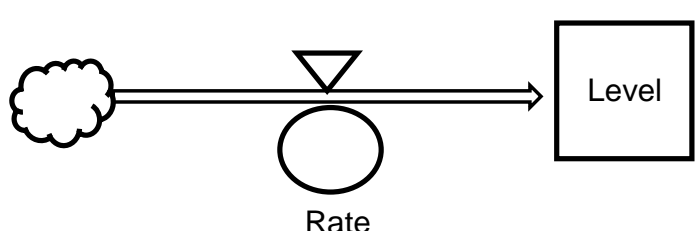

Figure 3. Rate and Level

c. Auxiliary Variable

Auxiliary variables are complementary variables that theoretically represent a policy structure better and clearer. If the auxiliary variables are omitted, the details of the policy structure cannot be reflected in the model.

\subsection{System Dynamic Model Diagram}

There are 2 diagram models in developing a System Dynamic model as follows:

a. Causal Loop Diagram

Cause and effect diagrams are disclosures about the events of cause and effect relationships in 
the view of certain images. the view of the picture is the arrows that are interlocking, thus forming a causal loop where the upstream of the arrow reveals the cause and the tip of the arrow reveals the effect. Both elements, both cause and effect, or just one of them (only cause or effect) must refer to the measurable state, both qualitatively for the felt state and quantitatively for the real state (actual). (Sushil, 1993).

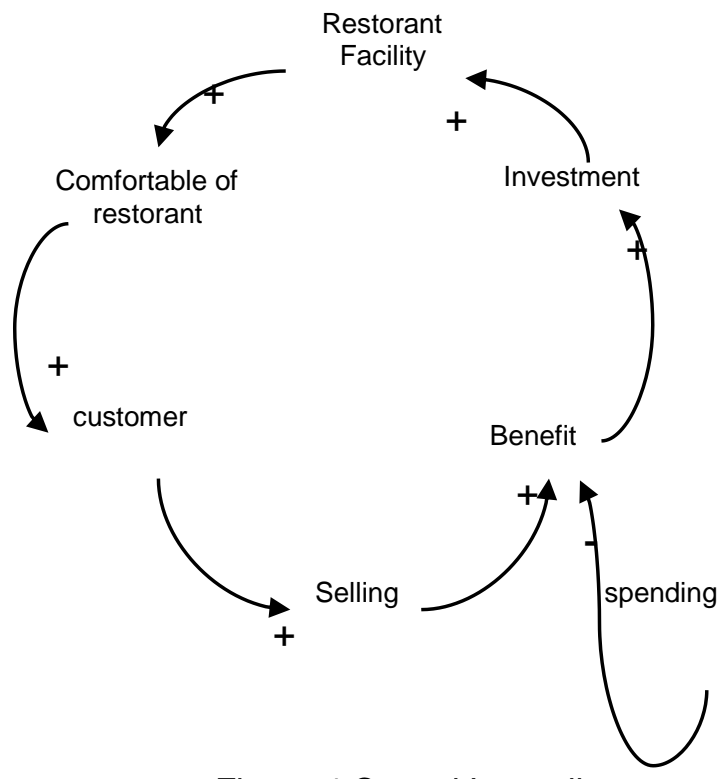

Figure 4 Causal Loop diagram

In Figure 4 above, Causal loop diagram is a process of preparing a model that is used to assemble a causal relationship into a closed system, so as to produce nodes (loops). The knot can be positive or negative. Positive if the change in the variable at the beginning of the flow causes an increase in the value of the variable at the end of the flow. Conversely, it is called negative if the variable change at the beginning of the flow causes a decrease in the end value of the flow.

b. Stock Flow Diagram

Stock Flow Diagram represents the flow structure in detail so that it can be used to construct mathematical models. The simulation flow diagram illustrates the relationship between variables and has been stated in the form of feedback structure symbols..

$$
\text { Rate }=\frac{\text { Goal }- \text { Level Awal }}{\text { Fraksi per satuan waktu }}
$$

There are four main elements of the feedback structure, namely: the goal (goal), the initial state (level), the difference between the goal-level, and the action (rate) that corrects the problem that requires adjustment time. The interaction of the four elements in the form of a flow chart can be seen in Figure 5.

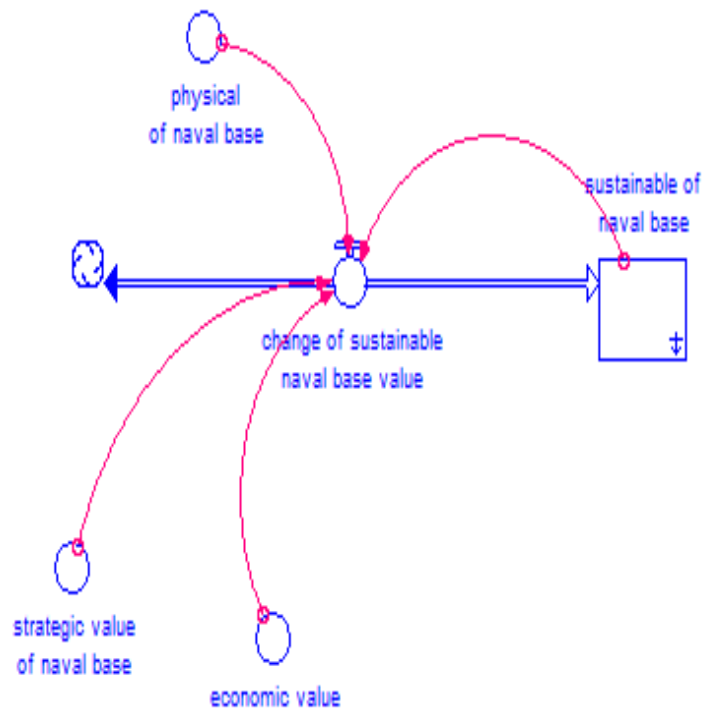

Figure 5. Stock Flow Diagram

\subsection{Fuzzy Weighting}

Data processing and looking for the value of the weight of the influence of the level of importance of aspects and Warshipteria in this paper using a method called the Fuzzy Weighting method (Suharyo, 2017), where the processing has levels up to 8 (eight) levels of processing. This method has the ease of filling questionnaires by experts and has a fairly good level of objectivity in determining assessments. The main objective of this model is to eliminate subjective judgments from experts by quantifying qualitative data from experts.

The data processing uses the Fuzzy weighting algorithm as follows: ( Suharyo, 2107)

a. Make the results of weighting the assessment of variable qualitative level aspects

b. Make the results of weighting a qualitative level assessment of Warshipteria variables

c. Determine the middle value of a fuzzy number d. Determine the upper and lower limit values of fuzzy numbers

e. Calculate the aggregate weights of each Warshipteria

f. Calculates the defuzzy value from the results of each qualitative Warshipteria assessment

g. Calculate the final weight value / level of importance of each Aspect Variable and criteria

\subsection{Research Methodology.}

To solve problems in the observed research, steps are needed and determined to describe the approach and model of the problem. The steps taken are: 


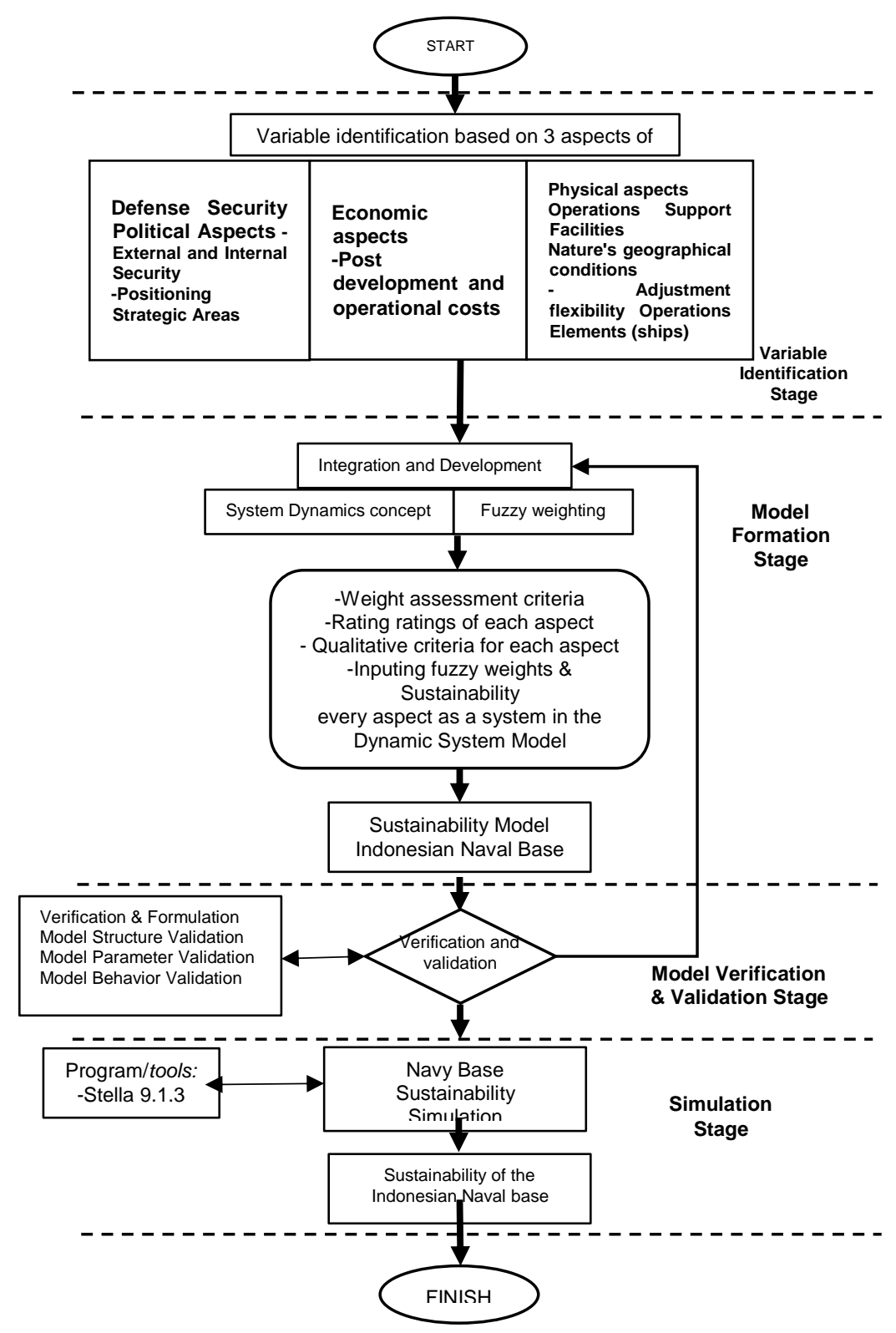

Figure 6. Research Methodology Flowchart.

3. RESULT AND DISCUSSION.

3.1. Weighting the Effect of Importance of Aspects and Variables

After identifying the main aspect variables and their criteria, the next step is to look for the weight of the influence of the importance and aspects of the variable which is a qualitative data obtained from the interviews of the experts / resource persons and questionnaires from each of the experts. This weighting is carried out with the aim to obtain the value or level of importance of each aspect variable and the criteria which will be used to determine the value of the importance of each variable in the formulation of the System Dynamic modeling used in the sustainability of the Navy Base.

The experts / informants in this study were determined in accordance with their respective positions and fields so that the experience regarding this matter was no doubt in looking at the situation and condition aspects that affect the sustainability of the Navy base. The experts / resource persons are in accordance with the following table :

Table 1. Research experts / sources

\begin{tabular}{|c|l|c|}
\hline NO & \multicolumn{1}{|c|}{ experts / sources } & office \\
\hline 1. & Navy Operations Staff (S1) & $\begin{array}{c}\text { naval } \\
\text { headquarters }\end{array}$ \\
\hline 2. & Navy Operations Staff (S2) & $\begin{array}{c}\text { naval } \\
\text { headquarters }\end{array}$ \\
\hline 3. & Operations staff officer (S3) & naval base \\
\hline 4. & $\begin{array}{l}\text { Expert Staff of the Naval } \\
\text { Base Facilities Facility (S4) }\end{array}$ & $\begin{array}{c}\text { naval } \\
\text { headquarters }\end{array}$ \\
\hline 5. & Operations Staff (S5) & $\begin{array}{c}\text { Main naval } \\
\text { base } \\
\text { Main naval } \\
\text { base }\end{array}$ \\
\hline 6. & Logistics Staff (S6) & $\begin{array}{c}\text { Main naval } \\
\text { base }\end{array}$ \\
\hline 7. & $\begin{array}{l}\text { Staff of the Base Facilities } \\
\text { Office (S7) }\end{array}$ \\
\hline
\end{tabular}


In this paper, the research instrument is divided into 2 parts as follows:

a. The first instrument is an in-depth interview with experts / sources to find a reference to the definition, identification and understanding of the concept of variable analysis of influential and interacting aspects that affect the sustainability of the Navy base.

b. The second instrument aims to find the value of each aspect variable based on qualitative assessments from experts / informants. Where the weight assessment is carried out on the main aspects of the sustainability of the Naval base and its sub-variables and criteria.

After the data in the field is sufficient, the next step is to recapitulate the data and process the data to get the weight value of the influence of the level of importance of the variables and criteria on the sustainability aspects of the Naval base.

\subsection{Data processing and weighting aspects and criteria}

The data processing uses the Fuzzy weighting algorithm as follows: (Suharyo, 2107)

a. Make the results of weighting the assessment of the variable level of qualitative aspects to get a quantitative value of aggregate weights.

\section{Aggregate Assessment of Main Aspects} From experts / sources

\begin{tabular}{|l|l|c|c|c|c|c|c|c|}
\hline NO & MAIN ASPECTS & S1 & S2 & S3 & S4 & S5 & S6 & S7 \\
\hline 1 & $\begin{array}{l}\text { Defense Security } \\
\text { Political Aspects }\end{array}$ & 9 & 9 & 8 & 9 & 8 & 8 & 7 \\
\hline 2 & $\begin{array}{l}\text { Aspect of } \\
\text { Economic }\end{array}$ & 7 & 7 & 8 & 9 & 6 & 6 & 6 \\
\hline 3 & $\begin{array}{l}\text { Aspect of Phisycal } \\
\text { naval base }\end{array}$ & 5 & 8 & 9 & 8 & 8 & 8 & 7 \\
\hline
\end{tabular}

b. Make the results of weighting an assessment of the variable level of qualitative criteria to get a quantitative value.

Aggregate Of Criteria Assessment In Defense Security Political Aspects from experts / sources

\begin{tabular}{|l|l|l|l|l|l|l|l|l|}
\hline NO & \multicolumn{1}{|c|}{ CRITERIA } & S1 & S2 & S3 & S4 & S5 & S6 & S7 \\
\hline 1 & Naval Base Strategic Area Position & 9 & 9 & 9 & 9 & 8 & 8 & 8 \\
\hline 2 & Regional Vulnerability & 8 & 9 & 8 & 8 & 8 & 8 & 8 \\
\hline 3 & Threat of Terosism at sea & 5 & 6 & 6 & 8 & 8 & 8 & 8 \\
\hline 4 & Crime in the sea & 6 & 8 & 8 & 7 & 8 & 8 & 7 \\
\hline 5 & IIlegal Fishing & 4 & 5 & 7 & 7 & 8 & 6 & 8 \\
\hline 6 & IIlegal Logging & 7 & 7 & 7 & 7 & 8 & 8 & 7 \\
\hline 7 & Piracy & 6 & 8 & 8 & 7 & 8 & 8 & 6 \\
\hline 8 & Smuggling & 6 & 8 & 8 & 8 & 8 & 8 & 9 \\
\hline 9 & Territorial Conflict & 4 & 6 & 8 & 9 & 3 & 5 & 6 \\
\hline 10 & Territorial Violations & 4 & 6 & 7 & 9 & 5 & 7 & 7 \\
\hline 11 & IIlegal immigrants & 6 & 7 & 6 & 9 & 8 & 5 & 9 \\
\hline 12 & Cyber attack & 6 & 4 & 5 & 7 & 4 & 5 & 7 \\
\hline
\end{tabular}

Aggregate of Criteria Assessment on Economic Aspect

\begin{tabular}{|l|l|l|l|l|l|l|l|l|}
\hline NO & \multicolumn{1}{|c|}{ CRITERIA } & S1 & S2 & S3 & S4 & S5 & S6 & S7 \\
\hline 1 & Regional total GRDP & 6 & 6 & 7 & 8 & 6 & 6 & 6 \\
\hline 2 & Industrial sector GRDP & 4 & 4 & 5 & 9 & 6 & 6 & 7 \\
\hline 3 & Other sectors' GRDP & 6 & 6 & 6 & 7 & 6 & 7 & 6 \\
\hline 4 & Living Cost of the people & 5 & 5 & 7 & 7 & 6 & 7 & 6 \\
\hline 5 & Availability of Base Land & 5 & 5 & 6 & 5 & 7 & 8 & 7 \\
\hline 6 & land capacity & 4 & 4 & 6 & 5 & 7 & 8 & 6 \\
\hline 7 & Industry Attractiveness & 5 & 5 & 7 & 9 & 7 & 7 & 6 \\
\hline 8 & Public and commercial port interests & 6 & 6 & 7 & 9 & 7 & 8 & 7 \\
\hline 9 & Business permit & 7 & 7 & 6 & 9 & 7 & 7 & 7 \\
\hline 10 & Business land & 7 & 7 & 7 & 9 & 7 & 7 & 7 \\
\hline 11 & Improvement of regional economy & 6 & 7 & 7 & 9 & 6 & 8 & 6 \\
\hline 12 & Investor & 6 & 6 & 7 & 9 & 6 & 7 & 7 \\
\hline 13 & Labor & 4 & 5 & 6 & 9 & 6 & 6 & 8 \\
\hline
\end{tabular}


Aggregate of Criteria Assessment on The Physical Of Naval Base Aspects

\begin{tabular}{|c|l|l|l|l|l|l|l|l|}
\hline NO & \multicolumn{1}{|c|}{ CRITERIA } & S1 & S2 & S3 & S4 & S5 & S6 & S7 \\
\hline 1 & Physical Condition of Naval Base & 5 & 5 & 7 & 8 & 8 & 8 & 7 \\
\hline 2 & Port Facilities & 5 & 5 & 8 & 7 & 8 & 8 & 7 \\
\hline 3 & Docking facilities & 4 & 4 & 7 & 8 & 8 & 6 & 6 \\
\hline 4 & Fuel Support Facility & 5 & 4 & 8 & 8 & 8 & 8 & 7 \\
\hline 5 & Facility maintenance support personnel & 4 & 4 & 7 & 8 & 8 & 7 & 7 \\
\hline 6 & Facilities maintenance and repair & 4 & 6 & 8 & 9 & 8 & 6 & 6 \\
\hline 7 & Warship operating intensity & 7 & 4 & 8 & 9 & 8 & 8 & 8 \\
\hline 8 & Naval Base Infrastructure & 6 & 6 & 8 & 9 & 8 & 8 & 7 \\
\hline 9 & Geotechnical Naval Base & 6 & 5 & 7 & 9 & 8 & 8 & 7 \\
\hline 10 & Hidro Oceanografi & 8 & 4 & 8 & 9 & 8 & 8 & 7 \\
\hline 11 & tide & 9 & 7 & 8 & 9 & 8 & 8 & 7 \\
\hline 12 & Sea level depth & 3 & 6 & 7 & 9 & 8 & 8 & 7 \\
\hline 13 & wind velocity & 7 & 4 & 6 & 9 & 8 & 8 & 7 \\
\hline
\end{tabular}

c. Determine the mean value of fuzzy numbers (at), by adding up the values that appear at each level of the linguistic scale and then dividing the results of the sum by the number of aspects or criteria whose values enter into the level of linguistic assessment. The mathematical notation is as follows

$$
a_{t}=\frac{\sum_{i=1}^{k} \sum_{j} T_{i j}}{\sum_{i=1}^{k} n_{i j}}
$$

$a_{t} \quad=$ the middle value of the fuzzy number for the grading level

$\mathrm{T}=$ assessment levels are very low, low, medium, high and very high.

$\mathrm{n} \quad=$ the number of criteria aspects of the T linguistic scale for the 1st Aspect of the i criteria

$\mathrm{T}_{\mathrm{ij}} \quad=$ numerical value of the $\mathrm{T}$ linguistic scale for the 1st aspect of the $\mathrm{j}$ criteria

d. Determine the lower boundary value (ct) and the upper boundary value (bt) fuzzy numbers, where the lower boundary value $(\mathrm{ct}=\mathrm{b}(\mathrm{i}-1))$ is the same as the midpoint value below it, whereas for the upper boundary value $(b t=b(i-1))$ is the same as the midpoint of the level above it.

e. Determine the aggregate weights of each qualitative criterion, because in this study a linguistic valuation form that already has a fuzzy triangular number is defined, then the aggregation process undertaken is to find the aggregate value of each lower boundary value (c), the middle value ( a) and the upper boundary value (b), which can be modeled as follows:

$$
c_{t}=\frac{\sum_{j=1}^{n} c_{t j}}{n}, a_{t}=\frac{\sum_{j=1}^{n} a_{t j}}{n}, b_{t}=\frac{\sum_{j=1}^{n} b_{t j}}{n}
$$

$\mathrm{C}_{\mathrm{tj}}$ limit value of $\mathrm{t}$ qualitative criteria by the $j$ decision maker

$a_{t j}=$ the middle value of the $t$ qualitative criteria by the $\mathrm{j}$ decision maker

$\mathrm{b}_{\mathrm{tj}}=$ value of the upper bound of the $\mathrm{t}$ qualitative criteria by the $\mathrm{j}$ decision maker

$\mathrm{n}$ = number of assessors (decision makers)

\section{Main Weight Aggregate Aspects}

\begin{tabular}{|l|l|c|c|c|}
\hline NO & \multicolumn{1}{|c|}{ MAIN ASPECTS } & ct & at & bt \\
\hline 1 & $\begin{array}{l}\text { Defense Security } \\
\text { Political Aspects }\end{array}$ & 6.56 & 8.17 & 9.43 \\
\hline 2 & Aspect of Economic & 4.82 & 7.02 & 8.40 \\
\hline 3 & $\begin{array}{l}\text { Aspect of Phisycal } \\
\text { naval base }\end{array}$ & 5.89 & 7.77 & 9.14 \\
\hline
\end{tabular}

\begin{tabular}{|c|c|c|c|c|c|c|c|c|c|c|c|c|c|c|c|c|c|c|c|c|c|c|}
\hline \multirow[t]{2}{*}{ No } & \multirow{2}{*}{$\begin{array}{c}\text { LEVEL } \\
\text { LINGUISTICS }\end{array}$} & \multicolumn{3}{|c|}{ S1 } & \multicolumn{3}{|c|}{ S2 } & \multicolumn{3}{|c|}{ S3 } & \multicolumn{3}{|c|}{ S4 } & \multicolumn{3}{|c|}{ S5 } & \multicolumn{4}{|c|}{ S6 } & \multicolumn{2}{|c|}{ S7 } \\
\hline & & ct & at & bt & ct & at & bt & ct & at & bt & $\mathrm{ct}$ & at & bt & ct & at & bt & ct & at & bt & ct & at & bt \\
\hline 1 & VERY LOW & & & & & & & & & & & & & & & & & & & & & \\
\hline 2 & LOW & 1.00 & 3.00 & 5.59 & 1.00 & 4.00 & 5.57 & 0.00 & 0.00 & 0.00 & 0.00 & 0.00 & 0.00 & $1.00 \mid$ & 3.33 & 5.91 & 0.00 & 0.00 & 0.00 & 0.00 & 0.00 & 0.00 \\
\hline 3 & MEDIUM & 3.00 & 5.59 & 7.40 & 4.00 & 5.57 & 7.68 & 1.00 & 5.75 & 7.44 & 1.00 & 5.00 & 7.50 & 3.33 & 5.91 & 7.79 & 3.00 & 5.69 & 7.72 & 3.00 & 6.00 & 7.27 \\
\hline 4 & HIGH & 5.59 & $7.40 \mid$ & 9.00 & 5.57 & 7.68 & 9.00 & 5.75 & 7.44 & 9.00 & 5.00 & 7.50 & 9.00 & 5.91 & 7.79 & 9.00 & 5.69 & 7.72 & 9.00 & 6.00 & $7.27 \mid$ & 9.00 \\
\hline 5 & VERY HIGH & 7.40 & 9.00 & 10.00 & 7.68 & 9.00 & 10.00 & 7.44 & 9.00 & 10.00 & 7.50 & 9.00 & 10.00 & 0.00 & 0.00 & 0.00 & 7.72 & 9.00 & 10.00 & 7.27 & 9.00 & 10.00 \\
\hline
\end{tabular}

Weight Aggregate Criteria Of Defense Security 
Weight Aggregate Criteria Of Defense Security Political Aspects

\begin{tabular}{|l|l|c|c|c|}
\hline NO & \multicolumn{1}{|c|}{ Criteria } & bb & bt & ba \\
\hline 1 & $\begin{array}{l}\text { Naval Base } \\
\text { Strategic Area } \\
\text { Position }\end{array}$ & 6.80 & 8.40 & 9.57 \\
\hline 2 & $\begin{array}{l}\text { Regional } \\
\text { Vulnerability }\end{array}$ & 5.95 & 7.73 & 9.14 \\
\hline 3 & $\begin{array}{l}\text { Threat of Terosism } \\
\text { at sea }\end{array}$ & 4.37 & 6.74 & 8.36 \\
\hline 4 & Crime in the sea & 5.27 & 7.28 & 8.77 \\
\hline 5 & Illegal Fishing & 4.38 & 6.32 & 8.14 \\
\hline 6 & Illegal Logging & 5.64 & 7.54 & 9.00 \\
\hline 7 & Piracy & 4.85 & 7.10 & 8.52 \\
\hline 8 & Smuggling & 5.45 & 7.53 & 8.91 \\
\hline 9 & Territorial Conflict & 3.61 & 5.72 & 7.60 \\
\hline 10 & Territorial Violations & 4.75 & 6.56 & 8.29 \\
\hline 11 & Illegal immigrants & 4.75 & 7.21 & 8.65 \\
\hline 12 & Cyber attack & 2.86 & 5.59 & 7.43 \\
\hline
\end{tabular}

Weight Aggregate Criteria Of Economic Aspect

\begin{tabular}{|c|c|c|c|c|}
\hline NO & Criteria & $\mathrm{bb}$ & bt & $\mathrm{ba}$ \\
\hline 1 & Regional total GRDP & 3.87 & 6.24 & 7.98 \\
\hline 2 & $\begin{array}{l}\text { Industrial sector } \\
\text { GRDP }\end{array}$ & 3.26 & 5.80 & 3.26 \\
\hline 3 & Other sectors' GRDP & 3.58 & 6.29 & 7.94 \\
\hline 4 & $\begin{array}{l}\text { Living Cost of the } \\
\text { people }\end{array}$ & 4.25 & 6.53 & 8.16 \\
\hline 5 & $\begin{array}{l}\text { Availability of Base } \\
\text { Land }\end{array}$ & 3.80 & 6.38 & 8.15 \\
\hline 6 & land capacity & 2.66 & 5.61 & 7.34 \\
\hline 7 & $\begin{array}{l}\text { Industry } \\
\text { Attractiveness }\end{array}$ & 4.98 & 7.02 & 8.48 \\
\hline 8 & $\begin{array}{l}\text { Public and } \\
\text { commercial port } \\
\text { interests }\end{array}$ & 5.41 & 7.20 & 5.41 \\
\hline 9 & Business permit & 5.32 & 7.52 & 8.92 \\
\hline 10 & Business land & 6.00 & 7.76 & 9.14 \\
\hline 11 & $\begin{array}{l}\text { Improvement of } \\
\text { regional economy }\end{array}$ & 4.83 & 7.05 & 8.49 \\
\hline 12 & Investor & 5.04 & 6.93 & 8.55 \\
\hline 13 & Labor & 3.69 & 6.03 & 7.89 \\
\hline
\end{tabular}

Weight Aggregate Criteria Of Physical of Naval Base Aspect

\begin{tabular}{|l|l|c|c|c|}
\hline NO & \multicolumn{1}{|c|}{ Criteria } & bb & bt & ba \\
\hline 1 & $\begin{array}{l}\text { Physical Condition of } \\
\text { Naval Base }\end{array}$ & 5.05 & 6.98 & 8.58 \\
\hline 2 & Port Facilities & 5.05 & 6.98 & 8.58 \\
\hline 3 & Docking facilities & 3.52 & 5.92 & 7.59 \\
\hline
\end{tabular}

\begin{tabular}{|l|l|c|c|c|}
\hline NO & \multicolumn{1}{|c|}{ Criteria } & bb & bt & ba \\
\hline 4 & Fuel Support Facility & 4.62 & 6.76 & 8.28 \\
\hline 5 & $\begin{array}{l}\text { Facility maintenance } \\
\text { support personnel }\end{array}$ & 4.34 & 6.39 & 8.02 \\
\hline 6 & $\begin{array}{l}\text { Facilities } \\
\text { maintenance and } \\
\text { repair }\end{array}$ & 4.59 & 6.73 & 8.30 \\
\hline 7 & $\begin{array}{l}\text { Warship operating } \\
\text { intensity }\end{array}$ & 5.78 & 7.45 & 8.95 \\
\hline 8 & $\begin{array}{l}\text { Naval Base } \\
\text { Infrastructure }\end{array}$ & 5.41 & 7.20 & 8.73 \\
\hline 10 & $\begin{array}{l}\text { Geotechnical Naval } \\
\text { Base }\end{array}$ & 5.41 & 7.20 & 8.73 \\
\hline 11 & Hidro Oceanografi & 5.35 & 7.23 & 5.35 \\
\hline 12 & tide & 6.00 & 7.76 & 9.14 \\
\hline 13 & Sea level depth & 5.12 & 6.83 & 8.47 \\
\hline 14 & wind velocity & 4.67 & 6.99 & 8.43 \\
\hline
\end{tabular}

f. The next step is to look for the criteria defuzzification value, where the defuzzification method used is the centroid method. The formula for defining criteria is as follows:

$$
=\frac{\left[\left[\int_{c_{t}}^{a_{t}} \frac{\left(x-c_{t}\right)}{\left(a_{t}-c_{t}\right)} x d x+\int_{a_{t}}^{b_{t}} \frac{\left(x-b_{t}\right)}{\left(a_{t}-b_{t}\right)} x d x\right]\right]}{\left[\left[\int_{c_{t}}^{a_{t}} \frac{\left(x-c_{t}\right)}{\left(a_{t}-c_{t}\right)} d x+\int_{a_{t}}^{b_{t}} \frac{\left(x-b_{t}\right)}{\left(a_{t}-b_{t}\right)} d x\right]\right]}
$$

with: $t=$ criteria $1,2,3$ n

g. The next stage is the processing of the Defuzzification value into the Final Weight Weight of each Criteria, by means of the Weight Value of each defuzzification criterion divided by the total number of weights of all the defuzzification criteria.

$\mathrm{NB} t=N t / \Sigma N t(1-n)$

$\mathrm{NBt}=$ The final weight value for each criteria

$N t=$ Defuzzification criteria weight value

$\Sigma N t(1-n)=$ Total weight value for all defuzzification criteria

FINAL VALUE OF MAIN ASPECTS

\begin{tabular}{|c|c|c|}
\hline NO & MAIN ASPECTS & FINAL WEIGHT \\
\hline 1 & $\begin{array}{c}\text { Defense Security } \\
\text { Political Aspects }\end{array}$ & 0.36 \\
\hline 2 & Aspect of Economic & 0.30 \\
\hline 3 & $\begin{array}{c}\text { Aspect of Phisycal naval } \\
\text { base }\end{array}$ & 0.34 \\
\hline
\end{tabular}


FINAL VALUE OF DEFENSE SECURITY POLITICAL ASPECTS

\begin{tabular}{|c|l|c|}
\hline NO & \multicolumn{1}{|c|}{ CRITERIA } & FINAL WEIGHT \\
\hline 1 & $\begin{array}{l}\text { Naval Base Strategic } \\
\text { Area Position }\end{array}$ & 0.083 \\
\hline 2 & Regional Vulnerability & 0.076 \\
\hline 3 & Threat of Terosism at sea & 0.065 \\
\hline 4 & Crime in the sea & 0.072 \\
\hline 5 & Illegal Fishing & 0.063 \\
\hline 6 & Illegal Logging & 0.074 \\
\hline 7 & Piracy & 0.069 \\
\hline 8 & Smuggling & 0.073 \\
\hline 9 & Territorial Conflict & 0.057 \\
\hline 10 & Territorial Violations & 0.066 \\
\hline 11 & Illegal immigrants & 0.069 \\
\hline 12 & Cyber attack & 0.053 \\
\hline
\end{tabular}

FINAL VALUE OF ECONOMIC ASPECTS

\begin{tabular}{|c|l|c|}
\hline NO & \multicolumn{1}{|c|}{ CRITERIA } & $\begin{array}{c}\text { FINAL } \\
\text { WEIGHT }\end{array}$ \\
\hline 1 & Regional total GRDP & 0.0685 \\
\hline 2 & Industrial sector GRDP & 0.0467 \\
\hline 3 & Other sectors' GRDP & 0.0674 \\
\hline 4 & Living Cost of the people & 0.0718 \\
\hline 5 & Availability of Base Land & 0.0694 \\
\hline 6 & land capacity & 0.0591 \\
\hline 7 & Industry Attractiveness & 0.0775 \\
\hline 8 & $\begin{array}{l}\text { Public and commercial port } \\
\text { interests }\end{array}$ & 0.0682 \\
\hline 9 & Business permit & 0.0824 \\
\hline 10 & Business land & 0.0867 \\
\hline 11 & $\begin{array}{l}\text { Improvement of regional } \\
\text { economy }\end{array}$ & 0.0772 \\
\hline 12 & Investor & 0.0777 \\
\hline 13 & Labor & 0.0667 \\
\hline
\end{tabular}

FINAL VALUE OF PHYSICAL ASPECT

\begin{tabular}{|c|l|c|}
\cline { 2 - 3 } NO & \multicolumn{1}{|c|}{ CRITERIA } & FINAL WEIGHT \\
\hline 1 & $\begin{array}{l}\text { Physical Condition of } \\
\text { Naval Base }\end{array}$ & 0.068 \\
\hline 2 & Port Facilities & 0.068 \\
\hline 3 & Docking facilities & 0.056 \\
\hline 4 & Fuel Support Facility & 0.065 \\
\hline 5 & $\begin{array}{l}\text { Facility maintenance } \\
\text { support personnel }\end{array}$ & 0.062 \\
\hline 6 & $\begin{array}{l}\text { Facilities maintenance } \\
\text { and repair }\end{array}$ & 0.064 \\
\hline 7 & $\begin{array}{l}\text { Warship operating } \\
\text { intensity }\end{array}$ & 0.073 \\
\hline
\end{tabular}

\begin{tabular}{|c|l|c|}
\cline { 2 - 3 } NO & \multicolumn{1}{|c|}{ CRITERIA } & FINAL WEIGHT \\
\hline 8 & $\begin{array}{l}\text { Naval Base } \\
\text { Infrastructure }\end{array}$ & 0.070 \\
\hline 10 & $\begin{array}{l}\text { Geotechnical Naval } \\
\text { Base }\end{array}$ & 0.070 \\
\hline 11 & Hidro Oceanografi & 0.059 \\
\hline 12 & tide & 0.075 \\
\hline 13 & Sea level depth & 0.067 \\
\hline 14 & wind velocity & 0.066 \\
\hline
\end{tabular}

3.3. Conceptualization of causal diagrams between entities in the main aspects of Naval Base Sustainability

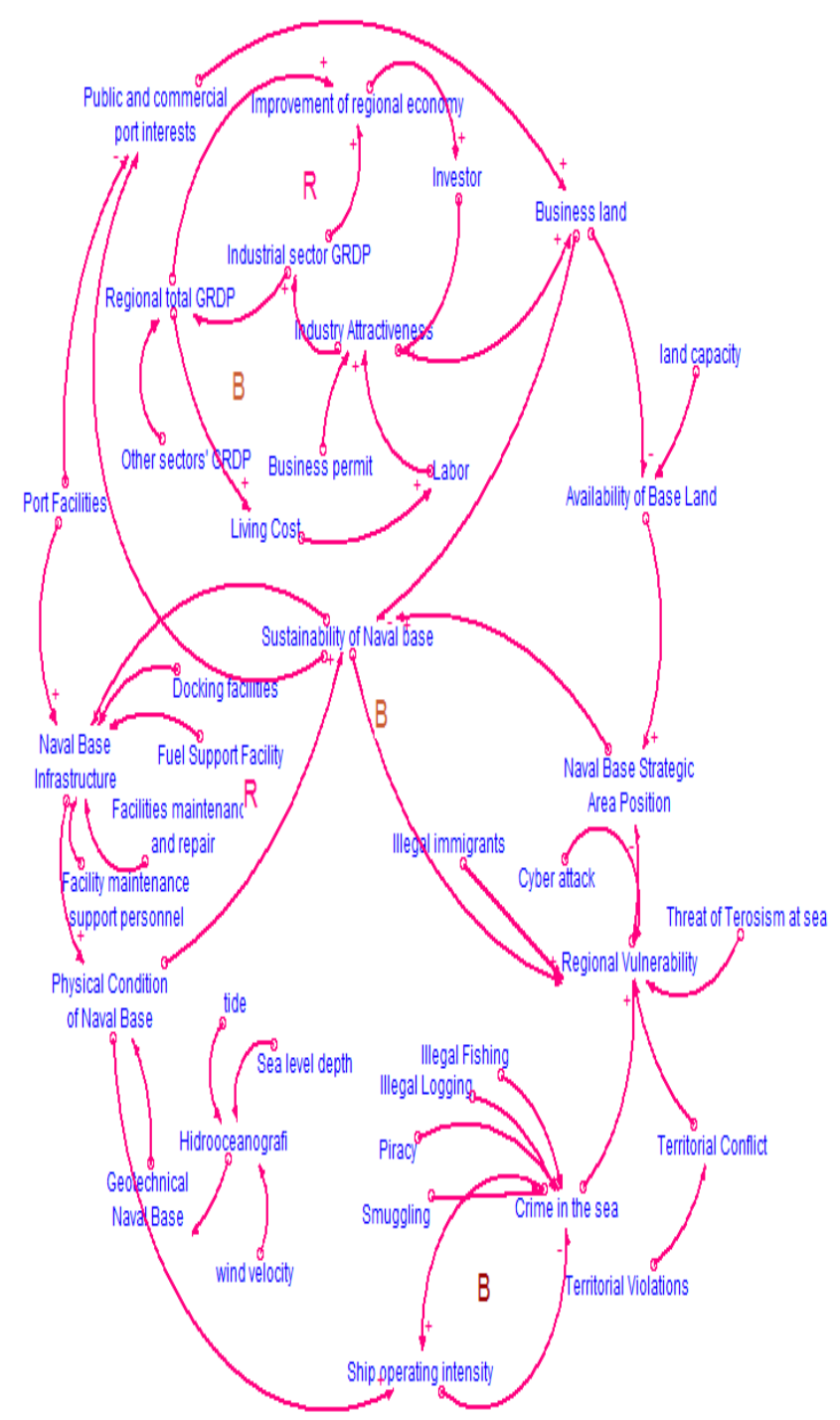

Figure 7. Causal Loop diagram of all the main aspects of the sustainability of naval Base

In Figure 7. above, a causal diagram explains that the Sustainability of the Navy Base is at the midpoint of a system. Where the point is influenced by the main aspect variables and their sub-variables. Sub-variables of each variable interact to affect one 
another, interact and form a pattern of relationships that are dynamic.

\subsection{Model Formulation of Defense Security Political Aspects}

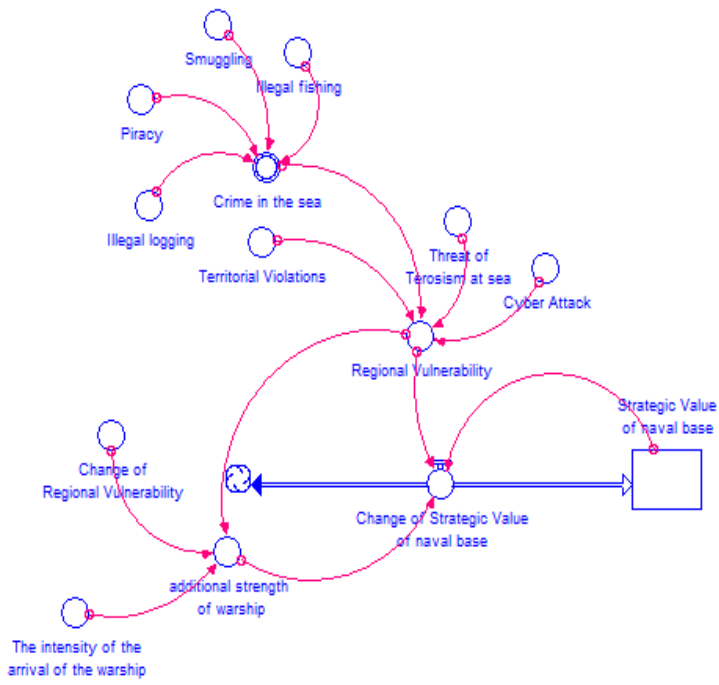

Figure 8. Formulation of Defense Security Political Aspects

\section{( Stella Version 9.1.3 isee ) Initialitation Equation}

Strategic Values__territories_Naval Base $(\mathrm{t})=$ Strategic Values__ Territories_Naval Base $(\mathrm{t}-\mathrm{dt})+$ (Change_value_strategies_posts) * $\mathrm{dt}$ INIT Strategic_Values_Naval Base_Cities $=4$ INFLOWS:

Change_value_strategic_post $=(0.072$ * region_ vulnerability $)+(0.073$ * incremental operational_Warship strength) - $(0 . \overline{083}$ *

Strategic_value _basis_region)

Terrorism Threat $=0.065$ * RANDOM $(4,6,1)$

UNITS: events / years

PHYSICAL ASPECT_DATE: Intensity_Red maturity_WARSHIP $=0.073 * 79$

UNITS: ship / year

fraction_change_representation_country $=1$

UNITS: ship / incident

Illegal_fishing $=4$

UNITS: events / years

Illegal_logging $=5$

UNITS: events / years

territorial_vulnerability $=$ (Terror_Threats +

Regional_Ingressions + Cyber_A Attack + sea_

criminality)

UNITS: events / years

criminal_di_laut $=0.072$ * (Illegal_fishing +

Illegal_logging + Smuggling + piracy _ \&_ Piracy)

UNITS: events / years

Region_violation $=0.066{ }^{*}$ RANDOM $(5,7,1)$

UNITS: events / years

power expression_explacement $=$

(PHYSICAL CHANGE ASPECT:

TREND_Intensity_WARSHIP) + (fraction change_definition_dependence_region * regional_ vulnerability)

UNITS: ship / year

Smuggling $=0.063$

UNITS: events / years

piracy_\&_Piracy $=0.069$

UNITS: events / years

Cyber_Attack $=0.053{ }^{*}$ RANDOM $(3,4,1)$

UNITS: events / years

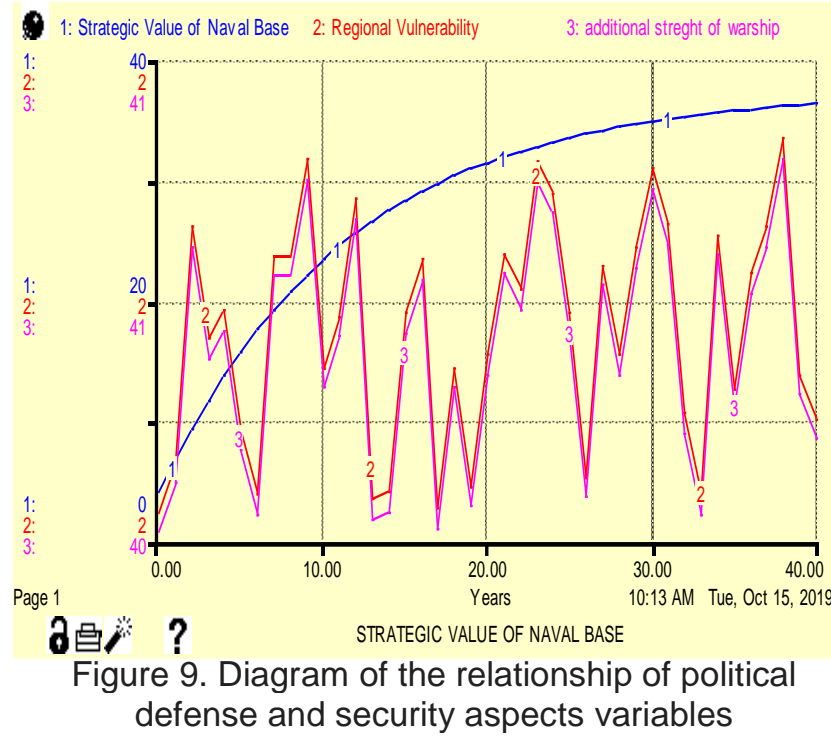

From Figure 3.3 the relationship between variables of the defense security political aspects, the strategic value of the base area increases from year to year until the 40th year. The increase in value is influenced by the region's vulnerability variable where the area's vulnerability rises, so the number of warships operating also increases. so there is no decrease in the strategic value of the region because the increase in the value of the area's vulnerability is always covered by the intensity of warships operating at the naval base. The strategic value of the base area for the next 40 years is 36.42 with a 2.05 area vulnerability and 41 warships in operation.

Table 2. Results of the strategic value of naval base area on Aspects of Political Defense Security

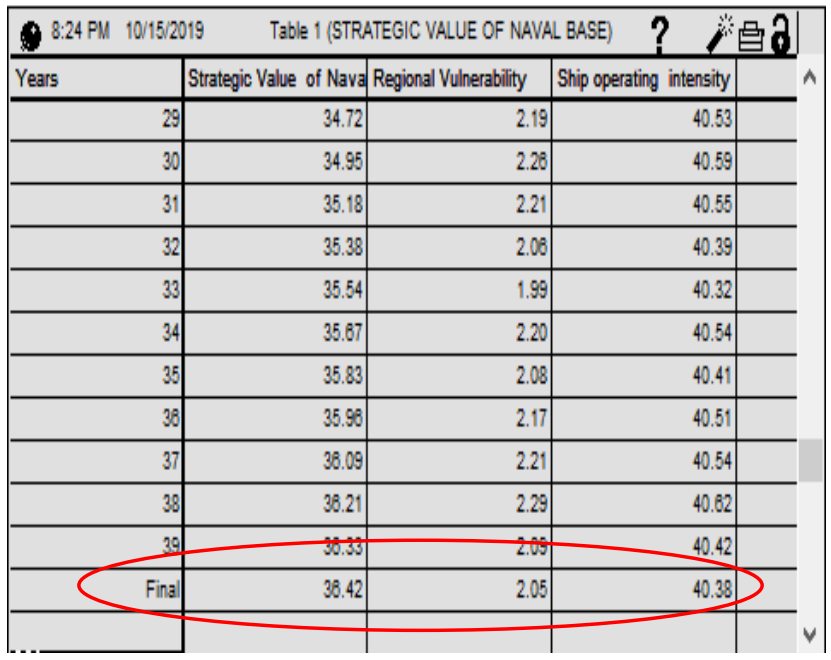




\subsection{Model Formulation of Economic Aspects}

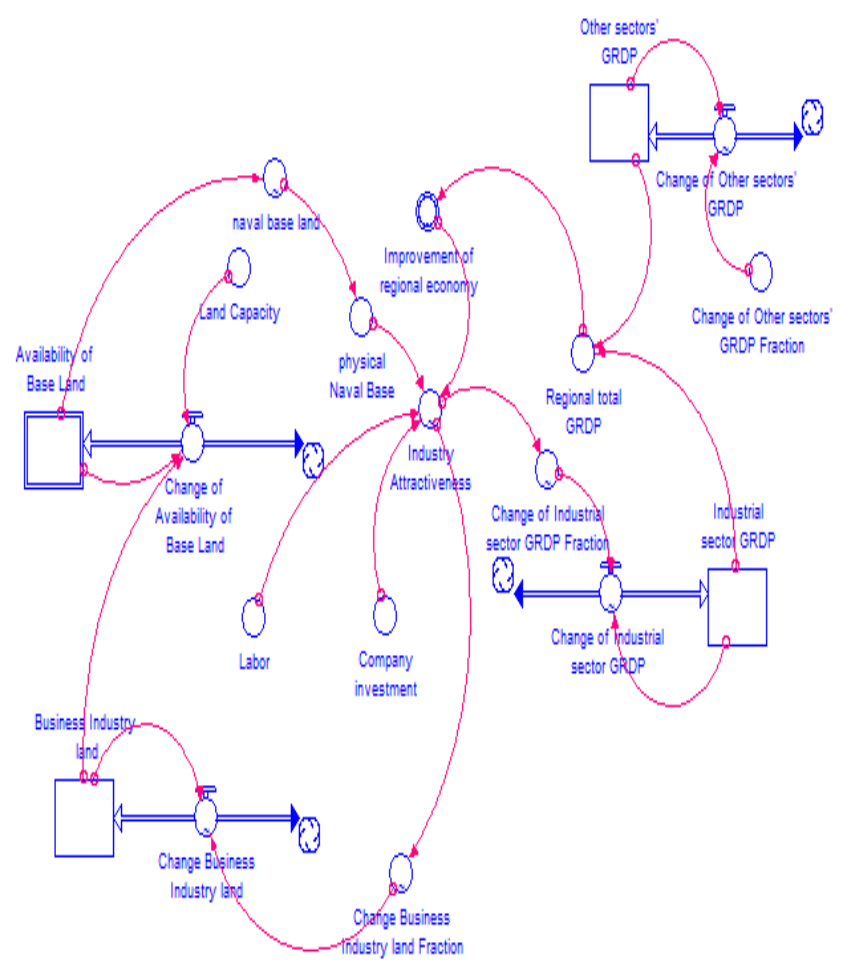

Figure 10. Formulation of Economic Aspects

\section{( Stella Version 9.1.3 isee ) Initialitation Equation}

Availability_of_Base_Land $(\mathrm{t})=$ Availability_of_Base_Land $(\mathrm{t}-\mathrm{dt})+$ (Change_of_Availability_of_Base_Land) ${ }^{*} \mathrm{dt}$ INIT Availability_of_Base_Land $=5$ DOCUMENT: the size of the index that states the availability of baseline land INFLOWS:

Change_of_Availability_of_Base_Land $=$ (Land_Capacity / Business_Industry_land) Availability_of_Base_Land Business_Industry_land $(\mathrm{t})=$ Business_Industry_land ( $\mathrm{t}-\mathrm{dt})+$ (Change_Business_Industry_land) * $\mathrm{dt}$ INIT Business_Industry_land $=8$ UNITS: ha

DOCUMENT: industrial land index INFLOWS:

Change_Business_Industry_land = GRAPH ((Business_Industry_land *

Change_Business_Industry_land_Fraction)) (0.00, 0.01), (10.0, 0.015), (20.0, 0.02), (30.0, 0.025), (40.0, 0.03), (50.0, 0.035), (60.0, 0.04), (70.0, 0.045), (80.0), , 0.05), (90.0, 0.055), (100, 0.06)

UNITS: hectares / time Industrial_sector_GRDP $(\mathrm{t})=$ Industrial_sector_GRDP $(\mathrm{t}-\mathrm{dt})+$ (Change_of_Industrial_sector_GRDP) * dt INIT Industrial_sector_GRDP $=2669500000$ UNITS: rupiah / year DOCUMENT: Gross Regional Domestic Product at Basic Prices in 2010 in the fisheries, forestry, agriculture and processing industry sectors in Karimun Regency, 2014-2018 (Source: BPS of Karimun Regency)

INFLOWS:

Change_of_Industrial_sector_GRDP $=$ GRAPH ((Industrial_sector_GRDP *

Change_of_Industrial_sector_GRDP_Fraction)) $(0.00,0.01),(10.0,9.50),(20.0,22.0),(30.0,21.5)$, (40.0, 26.0), (50.0, 28.5), (60.0, 32.0), (70.0, 43.0), (80.0) , 51.0), (90.0, 84.5), (100, 92.0)

UNITS: rupiah / year-time

Other_sectors' _ GRDP (t) $=$ Other_sectors' GRDP $(\mathrm{t}-\mathrm{dt})+$ (Change_of_Other_sectors' GRDP) * $d t$

INIT Other sectors' GRDP $=6348150000$

UNITS: rupiah / year

DOCUMENT: GDP value at constant prices in sectors other than the fishing, forestry, agriculture and processing industries in the Karimun Regency (source BPS, Karimun Regency)

INFLOWS:

Change_of_Other_sectors' _ GRDP $=$ GRAPH ((Other sectors' - GRDP + Change_of_Other_sectors' _ GRDP_Fraction)) (0.00, 0.01), (10.0, 11.5), (20.0, 16.5), (30.0, 31.0), (40.0, 31.5), (50.0, 30.0), (60.0, 41.5), (70.0, 46.0), (80.0) , 57.0), (90.0, 67.0), (100, 82.5)

UNITS: rupiah / year-time

Change_of_Other_sectors' _ GRDP_Fraction =

RANDOM $(0.14,0.17 .1)$

UNITS: rupiah / year

DOCUMENT: the proportion of changes in the value of GRDP at constant prices

Company_investment $=1047123168196$

UNITS: rupiah

DOCUMENT: total investment of foreign and domestic investment companies in non-FTZ areas according to sub-districts in Karimun district (source: Integrated investment and licensing agency) Labor $=163003$

UNITS: people / yr

DOCUMENT: Total Population Aged 15 Years and Over by Type of Activity During the Past Week and Gender in

Karimun District, 2018 (source: National Labor Force Survey August)

Land_Capacity $=32,704$

UNITS: ha

DOCUMENT: existing base land this year physical_Naval_Base = naval_base_land DOCUMENT: ifisical from a base

Regional_total_GRDP = Other_sectors' _ GRDP + Industrial_sector_GRDP

DOCUMENT: The amount of GRDP in the total area of the manufacturing sector and other sectors.

The manufacturing sector has a greater contribution than other sectors so that it is made at its own level. data: BPS

Change_Business_Industry_land_Fraction = GRAPH (Industry_Attractiveness) 
(0.00, 0.00), (0.1, 0.001), (0.2, 0.001), (0.3, 0.002), $(0.4,0.002),(0.5,0.003),(0.6,0.006),(0.7,0.007)$, $(0.8,0.007),(0.9,0.008),(1,0.009)$

UNITS: ha

Change_of_Industrial_sector_GRDP_Fraction = GRAPH (Industry_Attractiveness)

(0.00, 0.015), (0.1, 0.035), (0.2, 0.06), (0.3, 0.105), $(0.4,0.1),(0.5,0.135),(0.6,0.13),(0.7,0.15),(0.8)$, $0.17),(0.9,0.195),(1,0.24)$

DOCUMENT: The magnitude of the percentage change in GRDP in the industrial sector

Improvement_of_regional_economy = GRAPH (Regional_total__GRDP)

$(0.00,0.015),(\overline{0.05}, 0.0575),(0.1,0.0775),(0.15$, $0.0975),(0.2,0.11),(0.25,0.118),(0.3,0.145),(0.35$, $0.168),(0.4), 0.208),(0.45,0.36),(0.5,0.42)$

UNITS: rupiah / year

DOCUMENT: an index that is defined as the level of macroeconomics in an area. Usually the assessment index is based on the level of GRDP per capita produced in an area

Industry Attractiveness $=$ GRAPH $(0.15$ *

Company_investment +0.3 * physical_Naval_Base +0.4 * Improvement_of_regional_economy +0.15 * Labor)

(0.00, 0.01), (0.007, 0.015), (0.014, 0.02), (0.021, $0.025),(0.028,0.03),(0.035,0.035),(0.042,0.04)$, $(0.049,0.045),(0.056), 0.05),(0.063,0.055),(0.07$, $0.055)$

UNITS: ha

DOCUMENT: Index defined as the value of investment attractiveness viewed from an overall perspective (macro-regional rather than sectoral) Data: Regional KPPOD

naval_base_land = GRAPH

(Availability_of_Base_Land)

(0.00, 0.135), (0.1, 0.24), (0.2, 0.335), (0.3, 0.425), $(0.4,0.525),(0.5,0.56),(0.6,0.6),(0.7,0.68),(0.8)$, $0.76),(0.9,0.86),(1,0.93)$

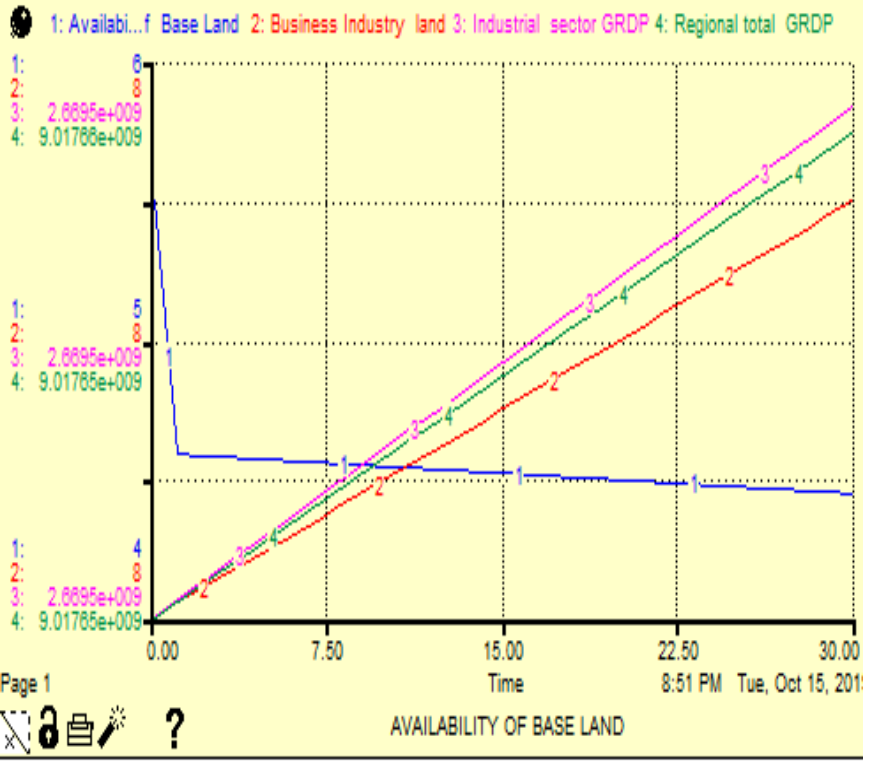

Figure 11. Diagram of the relationship of Economic aspects variables
From Figure 11 the relationship between economic aspects variables, the value of land availability from year to year decreases until the 40th year. The decline in value is influenced by the presence of industrial land in which the industrial sector business land rises, the industrial sector's GRDP also rises which pushes up the total GRDP of a area. With this, the value of land availability will decrease year after year. The value of land availability for the next 40 years is 3.94 with industrial sector business land at 8.30 .

Table 3. Results of the Availability of base land on Economic Aspects

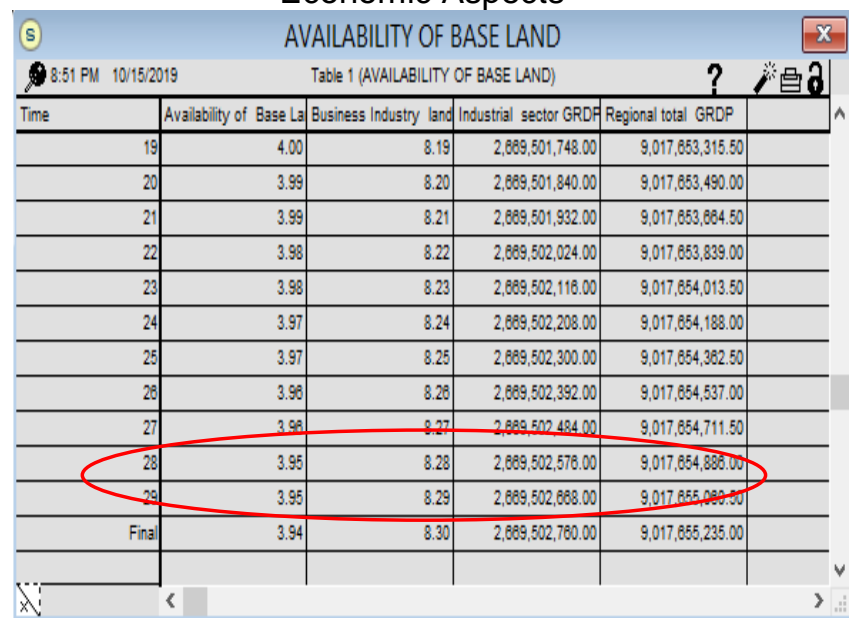

\subsection{Model Formulation of Economic Aspects}

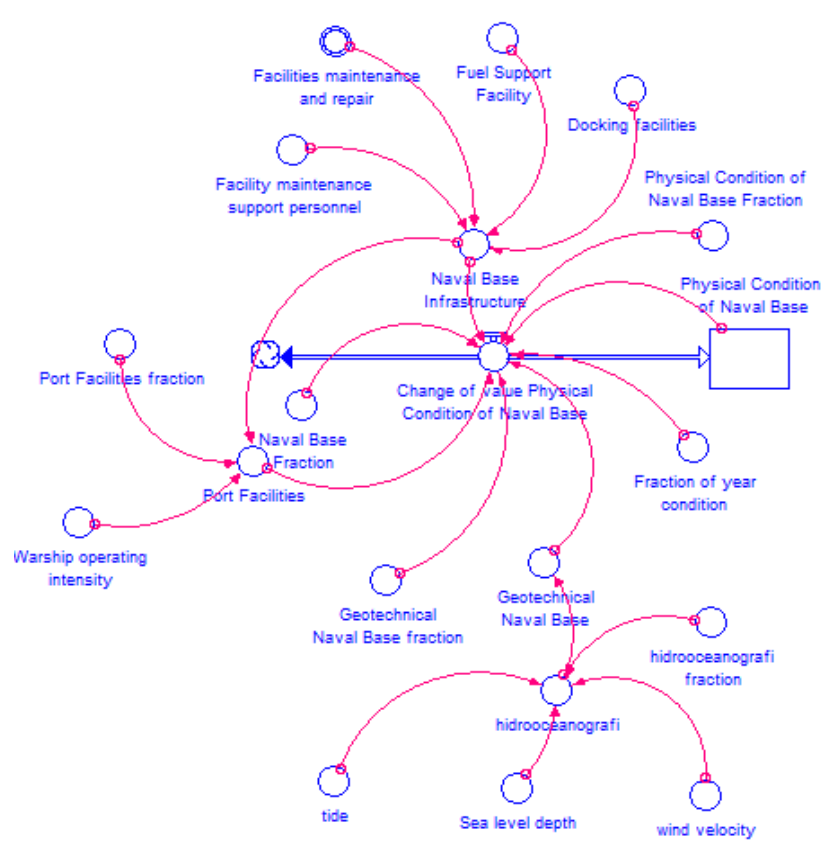

Figure 12. Formulation of Physical of Naval Base Aspects

\section{( Stella Version 9.1.3 isee ) Initialitation Equation}

Physical_Condition_of_Naval_Base $(\mathrm{t})=$ Physical_Condition_of_Naval_Base $(\mathrm{t}-\mathrm{dt})+$ 
(Change_of_value_Physical_Condition_of_Naval_Ba $\mathrm{se})^{*} \mathrm{dt}$

INIT Physical_Condition_of_Naval_Base $=4$

UNITS: unit

INFLOWS:

Change_of_value_Physical_Condition_of_Naval_Ba se $=\left(0.070^{*}\right.$ Naval_Base_Infrastructure $)+(0.073$ * Port_Facilities * Naval_Base_Fraction $)+(0.070$ *

Geotechnical_Naval_Base *

Geotechnical_Naval_Base_Fraction_Condition_Co ndition_Conditionion *

UNITS: unit / yr

Docking_facilities $=0.053{ }^{*}$ RANDOM $(6,8,1)$

UNITS: unit / yr

Facilities_maintenance_and_repair $=0.064$ *

RANDOM $(3,5,1)$

UNITS: unit / yr

Facility_maintenance_support_personnel $=0.066$ *

RANDOM $(5,7,1)$

UNITS: unit / yr

Fraction_of_year_condition $=1$

UNITS: $1 / \mathrm{yr}$

Fuel_Support_Facility $=0.065$ * RANDOM $(4,6,1)$

UNITS: unit / yr

Geotechnical_Naval_Base =hydrooceanography

UNITS: $m$

Geotechnical_Naval_Base_fraction $=1$

UNITS: unit / $\mathrm{m}$

hidrooceanografi $=$ (wind_velocity *

hidrooceanografi_fraction) + tide + Sea_level_depth

UNITS: $m$

hidrooceanografi_fraction $=1$

UNITS: $s$

Naval_Base_Fraction $=1$

UNITS: unit / ship

Naval_Base_Infrastructure $=$

(Fuel_Support_Facility +

Facility_maintenance_support_personnel +

Docking_facilities +

Facilities_maintenance_and_repair)

UNITS: unit / yr

Physical_Condition_of_Naval_Base_Fraction $=1$

UNITS: $\overline{1} / \mathrm{yr}$

Port_Facilities $=($ Warship_operating_intensity $)+$

(Port_Facilities_fraction *

Naval_Base_Infrastructure)

UNITS: ship / yr

Port_Facilities_fraction $=1$

UNITS: ships / units

Sea level_depth $=\operatorname{RANDOM}(0.4,21,1)$

UNITS: $m$

tide $=$ RANDOM $(0.6,4,1)$

UNITS: $m$

Warship_operating_intensity $=0.073^{*}$ MEAN

$(21,41,53)$

UNITS: ship / yr

wind_velocity $=0.5{ }^{*}$ RANDOM $(2,5,1)$

UNITS: $\mathrm{m} / \mathrm{s}$

DOCUMENT: $1 \mathrm{knot}=0.5 \mathrm{~m} / \mathrm{s}$. the level of wind speed in the 2017 Karimun district area based on the Raja Haji Abdullah meteorological station Tanjung Balai Karimun

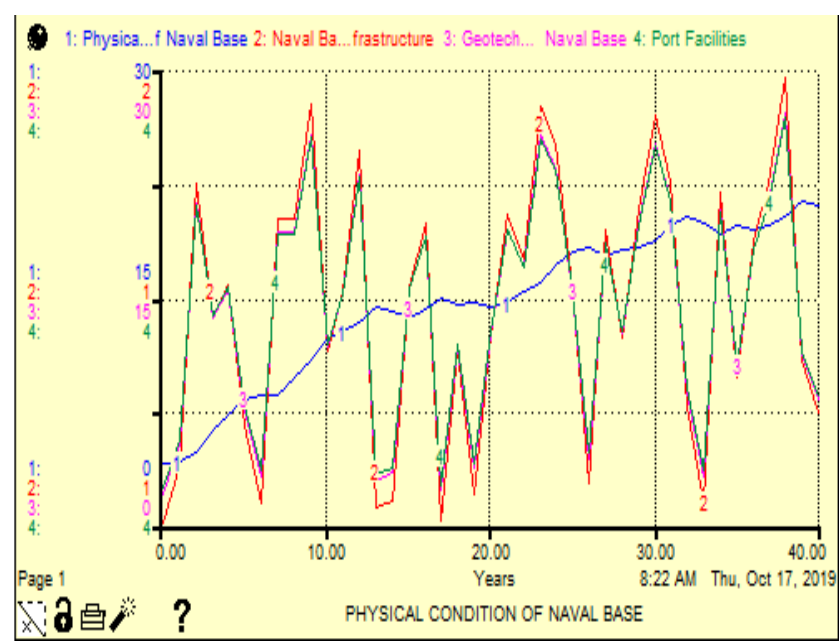

Figure 13. Diagram of the relationship of Physical of Naval Base aspects variables

From Figure 13. the relationship between variables from the physical base, the value of the base physical capability increases significantly from year to year until the 40th year. The increase in value is influenced by variable base infrastructure, base dock facilities and base geotechnics so. The base physical ability value for the 40th year is 21.07 (sustainable).

Table 4 Results of the Physical Condition of Naval

Base on Physical of Naval Base Aspects

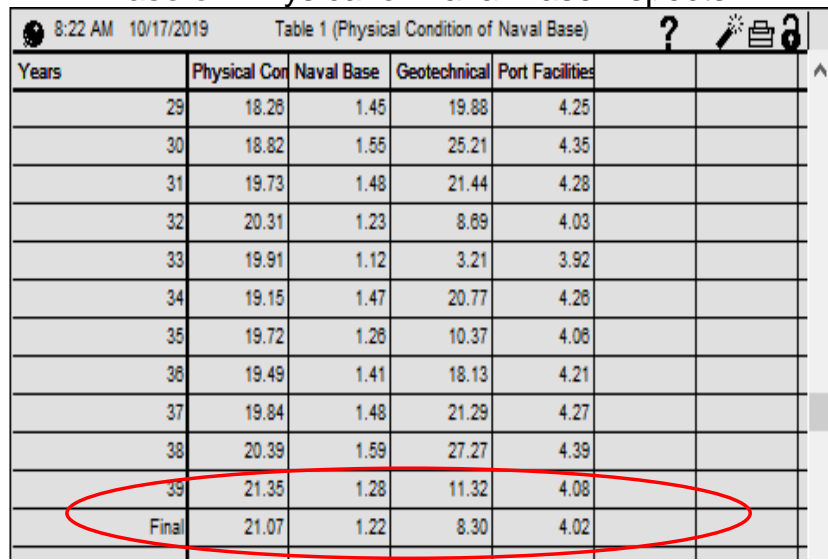

4. CONCLUSION.

In this paper, the model of naval base sustainability uses System Dynamic model formulation that is integrated with the weight value of the influence of the level of importance of Fuzzy Weighting, which in fact can affect one another. The formulation can produce a level of base sustainability which is projected until the 40th year with sustainable results. Meaning that a base can be sustainable in accordance with the function and use of the base as one of the elements of maritime defense and security in Indonesia.

This study uses 3 main aspects in measuring the level of sustainability of a naval base, namely the of defense security political aspects, economic aspects and physical of naval base aspects. Where the strategic value of the area of a base represents 
the condition of defense security political aspects that can improve the function of the base, the value of land availability represents the economic aspect that can shift or clamp a base, and the value of the physical capability of the base represents the condition of the physical aspect of the base that can enhance the function of the base.

The sustainability of naval bases is the dynamic conditions of bases that represent the sustainability of bases in accordance with their function in supporting maritime defense and security in Indonesia.

\section{REFERENCES.}

Alisjahbana, A. S., Yusuf, A. A., Anna, Z., Hadisoemarto, P. F., Kadarisman, A., Maulana, N., . . . Megananda. (2018). ADVANCING SDGS Preparedness Areas in Indonesia. Bandung: Unpad Press.

Blanc, D. (2015). Towards Integration at Last? The Sustainable. DESA Working Paper No. 141.

Faslanal. (2015). the book Title Navy Base. Jakarta: TNI AL.

Firmansyah, A. (2017). Dynamic System Model for Smart Economy Development (Case Study: Surabaya City). JURNAL TEKNIK ITS.

Forester, J. W. (1994). System Dynamic, System Thinking and Soft OR. Massachusetts: Massachusetts Institute of Technology.

Naval Headquarters. (2013). Instructions for Administration of Navy Base Standardization. Jakarta: Indonesian Navy

Nurhasanah, N. (2014). Dynamic System Simulation to Predict the Success of Laboratory Development Strategies Laboratory Development Strategies. Jurnal $A L-A Z H A R$ INDONESIA SERI SAINS DAN TEKNOLOGI, 129-142.

ODI. (2015). Projecting Progress: Reaching the SDGs by 2030.

Roy, B. (1968). Ranking and selection in the presence of multiple perspectives. RAIROOperations Research 2 (1), 57-75.

Rozikin, M. (2012). Analysis of the Implementation of Sustainable Development in Batu City. Jurnal Review Politik Vol.2 no.2, 219 - 243.

Sachs, D. (2012). The Age of Sustainable Development. New York: Columbia University Press.
Sugiyono. (2009). Educational Research: $A$ Qualitative Quantitative Approach, and R\&D. Bandung: Alfabeta.

Suharyo, O. S. (2017). Base Location Determination Model. Surabaya: Fakultas Teknologi Kelautan ITS.

Supardi, S. (2017). Analysis of Sustainability Development in Tepian City (Case Study: Baubau City, Sulawesi Province). Jurnal Wilayah dan Lingkungan, 188-204.

Sushil. (1993). System Dynamic ; A Practical Approach for Managerial Problem. USA: Wiley Eastern Limited.

Tustanovski, E. (2015). Testing the sustainability of the Croatian military forces: A system dynamics approach. Croatian Operational Research Review CRORR 6, 55-70.

UN. (2015). Transforming Our World: The 2030 Agenda For Sustainable.

Wang, J. (2017). Using System Dynamics to study Army Reserve deployment sustainability. 22nd International Congress on Modelling and Simulation, Hobart, Tasmania, Australia, 640-645.

Wijayanti, L. (2012). Analysis of Sustainability Development in Tepian City (Case Study: Baubau City, Sulawesi Province). Biro Penerbit Planologi Undip Volume 8 (2), 126137. 